It is suggested that this may be due to the increased activity of the pituitary bodies of the light-treated animals, resulting in an increased output of either growth hormone or thyrotrophic hormone.

Canterbury Agricultural College,

D. S. HaRT

University of New Zealand,

Lincoln College P.B.,

Christehurch.

June 25.

1 Yeates, N. M. T., J. Agric. Sci., 39, 1 (1949).

${ }^{2}$ Hart, D. S., J. Agric. Sci., 40, 143 (1950).

${ }^{3}$ Hammond, jun., J., Nature, 167, 150 (1951).

\section{Transfer of Labelled Nitrogen from Glutamic Acid to Pine Seedlings through the Mycelium of Boletus variegatus (Sw.) Fr.}

Is a previous paper from this Institute ${ }^{1}$ it was shown, by using the isotope technique, that hyphæ of Boletus variegatus (Sw.) Fr. in mycorrhizal connexion with pine seedlings transfer nitrogen from a solution of an ammonium salt to the roots. The labelled nitrogen was added as ammonium nitrate containing the stable isotope nitrogen-15 in the ammonium group. By a special arrangement, only the mycelium was exposed to the isotope, and then the amounts of nitrogen-15 were measured in different parts of the seedlings.

We have now studied in the same way the transfer of labelled nitrogen from an organic source to pine seedlings by means of mycorrhizal mycelium.

The nitrogen source chosen was glutamic acid. It has been recently demonstrated in this Institute ${ }^{3}$ that the growth-rate of many mycorrhizal fungi is increased by certain amino-acids in a nutrient solution containing also ammonium-nitrogen. The growthrate of Boletus variegatus is much increased, particularly by glutamic acid, under these experimental ccnditions. As a sole source of nitrogen, however, glutamic acid--in contrast to aspartic acid-yielded only a very poor mycelial growth. This seems to indicate that glutamic acid was not deaminated in any high degree by the fungus mycelium. Therefore, labelled glutamic acid seemed suitable for use as a tracer compound.

The experimental method used was as previously described $^{3}$. In wide-necked 500-ml. Erlenmeyer flasks were placed cups near the wall. Both vessels were supplied with purified sand to which was added a nutrient solution containing ammonium phosphate as source of nitrogen. Into each of the Erlenmeyer flasks one aseptic seedling of Pinus sylvestris was introduced, and after some time mycelium of Boletus variegatus was inoculated in the cups. The cultures were grown during the spring and summer of 1951.

Glutamic acid labelled with nitrogen-15 was kindly synthesized by Dr. S. Wideqvist, Chemical Institute, University of Uppsala. It contained $6 \cdot 3$ atomic per cent of nitrogen-15.

When mycorrhizæ had become well developed, the labelled amino-acid was added to the glass cups in amounts of $50 \mathrm{mgm}$., that is, about $4.5 \mathrm{mgm}$. nitrogen. To the sand outside the cups were supplied corresponding quantities of unlabelled acid, to prevent, if possible, diffusion from the hyphæ. Half the cultures were harvested after one and a half days, the others after three days, of exposure.
The seedlings were divided into two sections, namely, (1) stem and needles, (2) the roots. The sections were then treated as previously described ${ }^{4}$.

The measurements of nitrogen-15 were made by Dr. G. Ryhage, at the Institute of Chemistry, Stockholm. The mass spectrometer used was of the Nier type and gave a maximal error of 0.002 atomic per cent nitrogen-15 excess when the quantity of total nitrogen was $10 \mu \mathrm{gm}$.

In the accompanying table are given the values of the dry weights of the different sections, their total nitrogen content and the atomic per cent nitrogen-15 excess. It is clearly shown that nitrogen has been transported through the Boletus mycelium to the pine roots. From the mycorrhizal roots the isotope has further been translocated to the different parts of the seedlings. It may be difficult to prove that the nitrogen really has been delivered to the host tissues as glutamic acid. It may have been transaminated, at least in part, to other amino-acids already in the hyphal cells, and also have entered directly into the metabolic pathways leading to the synthesis of protein.

ATOMIC PER CENT NITROGEN-15 EXCESS IN PINE SEEDLINGS GRowN IN MXCORRHIZAL CONNEXION WITH Boletus variegatus EXPOSED TO

\begin{tabular}{|c|c|c|c|c|}
\hline $\begin{array}{l}\text { Plant } \\
\text { No. }\end{array}$ & $\begin{array}{l}\text { Portion of } \\
\text { seedling }\end{array}$ & $\begin{array}{c}\text { Dry weight } \\
\text { (mgm.) }\end{array}$ & $\begin{array}{c}\text { Total nitrogen } \\
\text { (mgm.) }\end{array}$ & $\begin{array}{l}\text { Atomic per cent } \\
\text { nitrogen-15 } \\
\text { excess }\end{array}$ \\
\hline $\begin{array}{r}\mathbf{I} \\
I I\end{array}$ & $\begin{array}{l}\text { Stem } \\
\text { Root } \\
\text { Stem } \\
\text { Root }\end{array}$ & $\begin{array}{c}1 \frac{1}{2} \text { days of ex } \\
97 \\
39 \\
103 \\
49\end{array}$ & $\begin{array}{c}\text { posure with the } \\
2.98 \\
1.16 \\
3.11 \\
1.43\end{array}$ & $\begin{array}{l}\text { sotope } \\
0.010 \\
0.031 \\
0.010 \\
0.036\end{array}$ \\
\hline $\begin{array}{l}\text { III } \\
\text { IV }\end{array}$ & $\begin{array}{l}\text { Stem } \\
\text { Root } \\
\text { Stem } \\
\text { Root }\end{array}$ & $\begin{array}{c}3 \text { days of ex } \\
109 \\
52 \\
99 \\
44\end{array}$ & $\begin{array}{c}\text { osure with the } \\
\begin{array}{c}3 \cdot 30 \\
1.62 \\
3 \cdot 02 \\
1 \cdot 31\end{array}\end{array}$ & $\begin{aligned} & \\
& 0.013 \\
& 0.059 \\
& 0.012 \\
& 0.052\end{aligned}$ \\
\hline
\end{tabular}

The experimental evidence leads to the assumption that nitrogen may be transferred to the root tissues through the Boletus mycelium from other aminoacids as well as glutamic acid. It may also be assumed that other mycorrhizal fungi of trees have the same ability as the fungus used in this experiment.

This investigation has been supported by a grant from Fonden för Skoglig Forskning, Stockholm.

\section{Elias MELIN}

H.arald Nilsson

Institute of Physiological Botany,

University of Uppsala. July 8.

${ }^{1}$ Melin, E., and Nilsson, H., Svensk Bot. Tidskr., 46 (1952).

${ }^{2}$ Melin, E., and Mikola, P., Physiol. Plant., 1, 109 (1948). Melin, E. and Norkrans, B., ibï., 1, 176 (1948). Norkrans, B., Symb. Bot. Upsal., 11, 1 (1950). Melin (unpublished).

${ }^{3}$ Melin, E., and Nilsson, H., Physiol. Plant., 3, 88 (1950).

'Melin, E., and Nilsson, H., Svensk Bot. Tidskr., 46 (1952).

\section{Effect of Boron and Molybdenum Fertilizers on Berseem (Trifolium alexandrinum)}

The cultivation of berseem, a leguminous forage crop, is gaining in importance in India on account of its high yields of succulent fodder of excellent nutritive value. Phosphatic fertilization of this legume has been found to be very beneficial ${ }^{x}$.

Brenchley and Thornton ${ }^{2}$, Midgley ${ }^{3}$, Naftel ${ }^{4}$ and others have shown that boron is essential for proper 